\title{
15: 78483887-78677329
}

National Cancer Institute

\section{Source}

National Cancer Institute. 15: 78483887-78677329. NCI Thesaurus. Code C41721.

Physical location of ARNT2_Gene 